\title{
Diet of sardine Sardina pilchardus: an 'end-to-end' field study
}

\author{
N. Nikolioudakis ${ }^{1,3, *}$, S. Isari ${ }^{1}$, P. Pitta ${ }^{2}$, S. Somarakis ${ }^{1}$ \\ ${ }^{1}$ Institute of Marine Biological Resources and ${ }^{2}$ Institute of Oceanography, Hellenic Centre for Marine Research, \\ Thalassocosmos, Heraklion 71003, Crete, Greece \\ ${ }^{3}$ Department of Biology, University of Crete, Heraklion 71409, Crete, Greece
}

\begin{abstract}
The diet of sardines was analyzed from samples collected at a coastal site in the North Aegean Sea (eastern Mediterranean) in July 2007 and July 2008 (stratification periods), and in December 2007 (early phase of the mixing period) and February 2009 (late phase of the mixing period). Concurrent measurements of environmental and planktonic community variables (from bacteria to mesozooplankton) were carried out to infer major trophic pathways in the pelagic food web and determine how these pathways are related to sardine prey selection. The bulk of the dietary carbon in adults was derived from calanoid copepods, $>1 \mathrm{~mm}$ total length, although the diet was numerically dominated by phytoplankton. In juveniles, phytoplankton consumption was negligible. The diet composition and prey selection seemed to be driven by the availability of large prey. During summer, microbial processes prevailed (the ratio of autotrophs $<20 \mu \mathrm{m}$ : $>20 \mu \mathrm{m}$ was 13 to 15, and the ratio of autotrophic to heterotrophic pico- and nanoplankton biomass was $<0.5$ ), the mean size of mesozooplankton was smaller, and filter-feeding cladocerans and appendicularians were very abundant. In February 2009, autotrophs $>20 \mu \mathrm{m}$ dominated the carbon budget, and the abundance of larger copepods (e.g. Centropages) was high. In December 2007, when waters were mixed but still relatively warm, both the 'microbial' and 'classical' (herbivorous) trophic pathways seemed to be important. The mean size of mesozooplankton (copepods and cladocerans) in sardine stomachs was highly correlated with their mean size in the field, and the latter was in turn highly positively correlated with the concentration of diatoms. Finally, a strong negative relationship between the Shannon-Wiener diversity index and average size of mesozooplankton prey in the stomachs was found, which could be explained in terms of the interplay of feeding modes, i.e. filter (non-selective) and particulate (selective) feeding.
\end{abstract}

KEY WORDS: Sardine $\cdot$ Sardina pilchardus $\cdot$ Diet $\cdot$ Food web $\cdot$ End-to-end

\section{INTRODUCTION}

Small pelagic fish (SPF) are highly opportunistic and flexible microphagous foragers (van der Lingen et al. 2009 and references therein). Their ability to switch between filter and particulate feeding (James 1988) has been proposed as a reason for their high abundances, especially in upwelling areas (van der Lingen et al. 2006). In most systems (upwelling or non-upwelling), SPF are found in species pairs (e.g. anchovies and sardines) that show size-based parti- tioning of the zooplankton resource, which is primarily used to derive the required energy (James 1988, van der Lingen et al. 2009). The out-of-phase fluctuations in the SPF biomass of upwelling systems have been suggested to be, at least partially, trophically mediated (Schwartzlose et al. 1999, van der Lingen et al. 2006), with a recent study providing strong support for this theory (Ayón et al. 2011).

The Mediterranean Sea is generally oligotrophic with a 'multivorous food web' (sensu Legendre \& Rassoulzadegan 1995), i.e. there are multiple energy 
transfer pathways between the 'classical' (herbivorous) food chain and the microbial loop (for a review, see Siokou-Frangou et al. 2010). The main planktivorous fishes in this area are sardines Sardina pilchardus and anchovy Engraulis encrasicolus (Palomera et al. 2007), which generally inhabit coastal areas with relatively high productivity (Somarakis et al. 2004, Giannoulaki et al. 2011). The North Aegean Sea is such an area, with increased productivity that is largely attributed to the influence of water from the Black Sea (Siokou-Frangou et al. 2010). Small copepods (mostly $<1 \mathrm{~mm}$ in total length) dominate mesozooplankton in this area in terms of both abundance and biomass (Isari et al. 2006, 2011, Zervoudaki et al. 2007). Microbial processes are enhanced in the food web, especially the carbon flow through microbial biomass (Siokou-Frangou et al. 2002) to filter-feeding mesozooplankters (e.g. cladocerans and appendicularians) (Isari et al. 2006, 2007).

The European sardine Sardina pilchardus is one of the most important fish resources in the North Aegean Sea (Antonakakis et al. 2011). Despite its importance for this ecosystem (Tsagarakis et al. 2010), there is no information on sardine feeding behavior in the North Aegean Sea. In the Atlantic, the same species efficiently exploits the lower part of the plankton size spectrum by filter or particulate feeding (Garrido et al. 2007a, 2008a). Zooplankton (especially smaller copepods and cladocerans) are the main energy source for sardines (Bode et al. 2004, Garrido et al. 2008a). However, phytoplankton can also be important in the diet of the Iberian sardine (Garrido et al. 2008a). In the western Mediterranean, sardines have been considered to be mainly zooplanktivorous, also consuming phytoplankton but in low proportions (Massuti \& Oliver 1948, Andreu 1969).

Knowledge of the trophic ecology of pelagic species and, more specifically, prey selection (in terms of taxa or size) is of great importance for quantifying trophic interactions and energy flows and particularly relevant for end-to-end ecosystem modeling (Rose et al. 2010). For small pelagic fishes that can switch between filter (non-selective) and particulate (selective) feeding, the structure and function of the planktonic food web is likely to significantly affect prey selection by ultimately determining the size structure of mesozooplankton, i.e. the availability of large copepods. Van der Lingen et al. (2006, 2009) have hypothesized that cold-water, diatomdominated systems favor large copepods, which can be exploited by anchovy using particulate feeding, whereas warm and stable waters, dominated by nanoflagellates, favor smaller copepods and, consequently, sardines (which can use their finer filtering apparatus to efficiently exploit smaller prey). In temperate waters, the structure and function of the planktonic food web changes seasonally, between the stratified (summer) and the mixed (winter) periods (Cushing 1978); thus, patterns of prey selection (in terms of size and type) may also vary seasonally in SPF.

Only a few field studies have analyzed the different components of the whole plankton assemblage, from bacteria to mesozooplankton, and further related the components to abiotic variables (Isari et al. 2007, Fileman et al. 2011). Furthermore, no such study has included higher trophic levels (fish). The main aim of the present study was to analyze the diet of sardines in relation to the structure of the planktonic food web. Sampling was conducted at a coastal site of the North Aegean Sea with high abundances of both adult and juvenile sardines (Nikolioudakis et al. 2011). This is to our knowledge the first study on sardines in the Mediterranean that assesses prey importance in terms of dietary carbon and prey sizes.

\section{MATERIALS AND METHODS}

\section{Fish sampling and handling}

Sardines were captured using a pelagic trawl at a shallow coastal area in the North Aegean Sea onboard the RV 'Philia' (see Fig. 1 in Nikolioudakis et al. 2011). The sampling was carried out in 4 sampling periods, namely July 2007, December 2007, July 2008 and February 2009. Once on deck, the sardine catch was sorted into 4 size classes: $40-80 \mathrm{~mm}$, 81-100 mm, 101-120 mm and >120 mm total length. Immediately after sorting, at least 20 fish per size class (when available) were frozen at $-35^{\circ} \mathrm{C}$. More details regarding the fish sampling are provided by Nikolioudakis et al. (2011). To describe dietary preferences, we used fish sampled at 3 different times of the same diel cycle in each sampling period, i.e. daytime, sunset and nighttime, because sardines initiated feeding soon after sunrise and continued to feed until the early hours of the night (Nikolioudakis et al. 2011).

In the laboratory, the fish were thawed, the stomachs were excised, and the prey was stored in $4 \%$ borax-buffered formaldehyde solution for later examination. Only material contained in the stomachs was considered, whereas the contents of the intestine and esophagus were discarded to reduce bias caused 
by different rates of digestion and gut passage times or cod-end feeding (Hyslop 1980). No signs of regurgitation due to sampling stress were recorded. Unidentifiable material was present in most of the stomachs excised (mainly remains of phytoplankton and zooplankton), but this material was not taken into account (van der Lingen 2002).

Pooling of the stomach contents of fish caught in the same haul to describe the diet of small pelagic fish is a common practice (e.g. Louw et al. 1998, van der Lingen 2002) because differences in individual diets are small. In the present study, the stomach contents of fish of the same size class, haul and sampling period were pooled and diluted to a known volume of filtered seawater $(0.2 \mu \mathrm{m})$. For mesozooplankton prey $(>200 \mu \mathrm{m}), 5 \mathrm{ml}$ aliquots, taken with a Stempel pipette, were examined under a stereomicroscope at a magnification of $80 \times$ until at least $10 \%$ of the sample was analyzed and prey were identified to the lowest possible taxonomic level. When mesozooplankton prey items were damaged, only heads were counted to avoid duplicate counting. For microphytoplankton and microzooplankton prey (20 to $200 \mu \mathrm{m}$ ), three $1 \mathrm{ml}$ aliquots were examined by inverted microscopy at a magnification of $400 x$. The numbers of all of the identified taxa were standardized to numbers per stomach. Literaturederived equations were used to convert the sizes of prey to carbon contents (see Table S1 in the supplement at www.int-res.com/articles/suppl/m453 p173_supp.pdf). Thirty randomly selected individuals (when available) from each identified taxon were photographed and measured. Apart from the dimensions necessary for carbon content conversions, the maximum length of each prey was also measured. In total, 36 samples (July 2007: 12, December 2007: 6, July 2008: 12, and February 2009: 6) were selected for the analysis of sardine diets.

\section{Environmental variables and plankton}

A large set of both abiotic and biotic variables were measured at 3 stations covering the mean trawling path (see Fig. 1 in Nikolioudakis et al. 2011). Vertical profiles of temperature and salinity were obtained at each station using a SBE-25 profiler. Depth-stratified water samples were also collected using Niskin bottles from 5 standard depths $(1,7,14,21$ and $28 \mathrm{~m})$ to estimate the concentration of dissolved inorganic nutrients $\left(\mathrm{NO}_{2}{ }^{-}, \mathrm{NO}_{3}{ }^{-}, \mathrm{PO}_{4}{ }^{3-}\right.$ and $\left.\mathrm{SiO}_{2}\right)$ and chlorophyll a ( $\mathrm{chl} \mathrm{a)}$ as well as the abundance of pico-, nano- and microplankton.
For chl a determination, seawater (0.5 l) was GF/F filtered (47 mm, Whatman). Both the filters and the filtrate were immediately frozen at $-35^{\circ} \mathrm{C}$. In the laboratory, chl a concentrations were determined fluorometrically (Yentsch \& Menzel 1963) using a Turner TD-700 fluorometer, while the filtrate was analyzed for phosphates, silicates, nitrites and nitrates according to Strickland \& Parsons (1972).

Water subsamples from Niskin bottles used to estimate the concentration of picoplankton (autotrophic cyanobacteria Synechococcus spp. [Syn] and heterotrophic bacteria [HB]) and nanoplankton (autotrophic [ANF] and heterotrophic [HNF] nanoflagellates) were preserved in borax-buffered formalin (final concentration 2\%). Subsequently, the samples were stained with DAPI, filtered on black polycarbonate filters $(25 \mathrm{~mm}$, Poretics) of porosity $0.2 \mu \mathrm{m}$ $(10 \mathrm{ml}$ for both HB and Syn) and $0.6 \mu \mathrm{m}(30 \mathrm{ml}$ for both ANF and HNF) and counted using epifluorescence microscopy (Porter \& Feig 1980). ANF and HNF cells were also distinguished into size classes, namely $<5 \mu \mathrm{m}, 5-10 \mu \mathrm{m}$ and 10-20 $\mu \mathrm{m}$. The abundances of picoplankton were converted into carbon biomass using conversion factors of $20 \mathrm{fg} \mathrm{C}^{\mathrm{C}} \mathrm{cll}^{-1}$ for HB (Lee \& Fuhrman 1987) and $250 \mathrm{fg} \mathrm{C} \mathrm{cell}^{-1}$ for Syn (Kana \& Glibert 1987). The abundances of ANF and HNF were first converted into biovolumes after measuring all of the dimensions and using simple geometric formulae and subsequently converted to car-

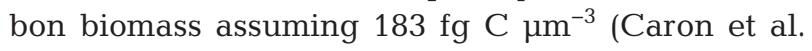
1995). For diatoms, dinoflagellates and ciliates (loricate and aloricate) samples were preserved in acid Lugol's solution $(2 \%)$ and identified by inverted microscopy after sedimentation of 10 to $100 \mathrm{ml}$, depending on the sample density, to the lowest possible taxonomic level. Dinoflagellates were distinguished as autotrophs (AD) or heterotrophs (HD) using literature-based feeding modes of each identified taxon (Tomas 1996). The abundances of diatoms and ADs were first converted into biovolumes using equations from Hillebrand et al. (1999) and subsequently converted to carbon biomass using equations from Menden-Deuer \& Lessard (2000) (Table S1 in the supplement).

Finally, vertical tows of plankton nets were performed to collect mesozooplankton and microplankton, as described by Nikolioudakis et al. (2011). Upon retrieval, the sample was split in half. The first subsample was used for biomass estimations. The second subsample was preserved in $4 \%$ borax-buffered formaldehyde solution. In the laboratory, the 50 to $200 \mu \mathrm{m}$ size fraction (obtained after sieving the microplankton sample through a $200 \mu \mathrm{m}$ sieve) was 
used to estimate the abundance of copepod nauplii, whereas the fraction $>200 \mu \mathrm{m}$ (the mesozooplankton sample) was used for taxonomic identification and abundance estimations of the major mesozooplankton taxa (e.g. copepods, cladocerans, doliolids, appendicularians, etc.). Copepods and cladocerans were identified to the species level when possible.

\section{Data analysis}

An analysis of variance (ANOVA) was used to compare each of the abiotic and biotic variables measured between the 4 sampling periods, after logarithmic transformation (Zar 1999). When the assumptions of ANOVA were not met, the non-parametric Kruskal-Wallis test was used. Bonferroni or Dunn's tests were used for parametric and non-parametric multiple comparisons, respectively (Zar 1999).

Multivariate techniques were applied to sardine diet data using PRIMER v6 (Clarke \& Gorley 2006) and the permutational multivariate analysis of variance (PERMANOVA)+ PRIMER add-on package (Anderson et al. 2008). The prey compositions (numbers per stomach) recorded for each haul, size class and sampling period were standardized and squareroot transformed prior to analysis. A similarity matrix based on the Bray-Curtis similarity index was then constructed and subjected to hierarchical agglomerative clustering (group average linkage) and multidimensional scaling (MDS) ordination (Field et al. 1982, Clarke \& Warwick 1994). Null hypotheses of no differences among the groups defined by both the cluster analysis and ordination were tested using PERMANOVA tests (Anderson et al. 2008). Unrestricted permutations (9999) of the raw data were used, and pair-wise tests were subsequently performed when appropriate. In each test, the null hypothesis of no significant differences among groups was rejected if the probability was $<0.05$. In cases in which the PERMANOVA detected significant differences, the similarity percentages (SIMPER) routine was utilized to identify which species made the greatest contributions to the observed differences (Clarke \& Warwick 1994). Fish $\leq 100 \mathrm{~mm}$ and fish $>100 \mathrm{~mm}$ were juveniles (captured only in summer, i.e. July 2007 and July 2008) and adults, respectively (see Nikolioudakis et al. 2011).

Diet overlap $(S)$ was quantified between juvenile and adult fish within each summer period and between adult fish for all sampling periods using Schoener's formula, $S=1-0.5 \sum P_{x i}-P_{y i}$, where $P_{x i}$ and $P_{y i}$ are the proportions of prey $i$ found in the diet of groups $x$ and $y$ (Schoener 1970). This index ranges from 0 (no diet overlap) to 1 (all food items in equal proportions). Index values $<0.33$ indicate a low overlap, while values $>0.67$ indicate high overlap (Moyle \& Senanayake 1984). The $S$ index was calculated based on both the numbers $\left(S_{(\mathrm{n})}\right)$ and carbon content $\left(S_{(\mathrm{C})}\right)$ of all of the prey identified in the stomachs. The specific selection for a given prey from those present in the ambient environment was assessed using the Ivlev's selectivity index: $E=\left(r_{i}-p_{i}\right)\left(r_{i}+p_{i}\right)^{-1}$, where $r_{i}$ is the relative concentration of prey category $i$ (in a percentage based on numeral abundance, $\%_{n}$ ) in the stomachs of sardines, and $p_{i}$ is the field concentration of that prey estimated from the plankton samples (Ivlev 1961). E ranges from -1 to +1 ; negative values indicate avoidance, and positive values indicate selection for a prey. Values close to zero indicate neutral selectivity. Only mesozooplankton prey with numerical contribution $>1 \%$ in the diet were included in the prey selectivity analysis.

Size-frequency histograms of prey were constructed based on both prey numbers and prey carbon content. Chain-forming diatoms were assigned to the size class corresponding to the maximum dimension of single cells because the chain length was unknown. Separate size-frequency histograms were also constructed for copepods and cladocerans in both the stomachs of adult sardines and the field samples. These groups were used because they encompassed the major mesozooplankton groups in the field during all sampling periods and they were always present in the stomachs of adult sardines, contributing $>1 \%$ to the dietary carbon. The weighted mean size $\left(\right.$ size $\left._{\text {diet }}\right)$ of ingested copepods and cladocerans in each sampling period was then calculated as the sum of the product of the number of individuals in each prey size class with the mean size corresponding to the size class, divided by the total number of prey in all size classes. The respective mean size was also calculated for the field $\left(\right.$ size $\left._{\text {field }}\right)$. Finally, the Shannon-Wiener diversity index $\left(H^{\prime}\right)$ was calculated for the copepod and cladoceran prey in the stomachs of adult sardines.

\section{RESULTS}

\section{Sardine diet}

In total, 603 stomachs of sardines were analyzed, and 47 taxa were identified belonging to 11 prey groups (see Table S2 in the supplement at www.int-res. com/articles/suppl/m453p173_supp.pdf). Mean prey 
numbers in the stomachs were highly variable, ranging from 83 to 3334 prey individuals in each stomach. A preliminary cluster analysis (data not shown) and MDS ordination, based on numbers of prey, demonstrated a clear differentiation in the diet composition of summer samples $(n=24)$ of fish with total lengths (TL) $\leq 100 \mathrm{~mm}$ from fish $>100 \mathrm{~mm}$ TL at the $38 \%$ similarity level (Fig. 1A). A PERMANOVA test ( $F=22.28$, $\mathrm{p}=0.0001$ ) and subsequent pairwise comparisons (Table 1) revealed significant differences in diet composition between juveniles ( $<100 \mathrm{~mm} \mathrm{TL})$ and adults (>100 mm TL) (Nikolioudakis et al. 2011). The same analysis for the samples from the mixing periods $(\mathrm{n}=$ 12) of fish $>100 \mathrm{~mm}$ TL showed no significant differences between the 101 to $120 \mathrm{~mm}$ and the $>120 \mathrm{~mm}$ size classes (PERMANOVA: $F=0.066, \mathrm{p}=0.969$ ). The percentages of numerical $\left(\%_{n}\right)$ and carbon $\left(\%_{C}\right)$ contribution of all identified prey items for each sampling period and ontogenetic stage can be found in Table S2.

Regarding major groups of ingested organisms, juvenile sardines fed heavily on copepods in both summers (on average $83 \%$ ), ingesting only negligible amounts of phytoplankton (on average $~ 5 \%$ ) (Fig. 2). In contrast, the diet of adults was numerically dominated by diatoms and ADs. A SIMPER analysis revealed that the discrimination of the diet between adults and juveniles was due to the diatoms Guinardia spp. and Coscinodiscus spp., the dinoflagellates Protoperidinium spp. and Neoceratium spp. and the ciliate Eutintinnus tubulosus (Tintinnida), which were the dominant prey in adult stomachs (see
Table S3 in the supplement). Juveniles mainly fed on the relatively large calanoid copepods Temora stylifera and Acartia clausi, the harpacticoid Euterpina acutifrons and the cyclopoid genus Oncaea (Table 2), also showing high selectivity $(E)$ for specific taxa with low abundance in the field (e.g. Microsetella rosea, cirriped larvae, etc.) (Table 2). Although the diets of juveniles and adults exhibited low overlap in terms of prey numbers $\left(S_{(\mathrm{n}) \text { July } 2007}=\right.$ $0.23, S_{(\mathrm{n}) ~ J u l y ~ 2008}=0.35$ ), when the carbon content of prey was considered (see Fig. 2 for major groups and

Table 1. Pairwise comparisons of diet composition between size classes in summer and between sampling periods for adults

\begin{tabular}{|lccc|}
\hline Groups & $t$ & $p$ & $\begin{array}{c}\text { No. of } \\
\text { unique per- } \\
\text { mutations }\end{array}$ \\
\hline Size classes (mm) & & & \\
40 -80 vs. 81-100 & 1.30 & 0.116 & 462 \\
$40-80$ vs. 101-120 & 3.32 & 0.002 & 462 \\
$40-80$ vs. >120 & 4.44 & 0.002 & 462 \\
$81-100$ vs. 101-120 & 2.87 & 0.002 & 462 \\
$81-100$ vs. >120 & 3.57 & 0.002 & 462 \\
$101-120$ vs. >120 & 1.12 & 0.257 & 462 \\
Sampling periods & & & \\
Jul 2007 vs. Dec 2007 & 4.22 & 0.002 & 461 \\
Jul 2007 vs. Jul 2008 & 2.33 & 0.003 & 462 \\
Jul 2007 vs. Feb 2009 & 3.05 & 0.002 & 462 \\
Dec 2007 vs. Jul 2008 & 5.35 & 0.002 & 462 \\
Dec 2007 vs. Feb 2009 & 5.42 & 0.001 & 461 \\
Jul 2008 vs. Feb 2009 & 5.26 & 0.002 & 462 \\
\hline
\end{tabular}

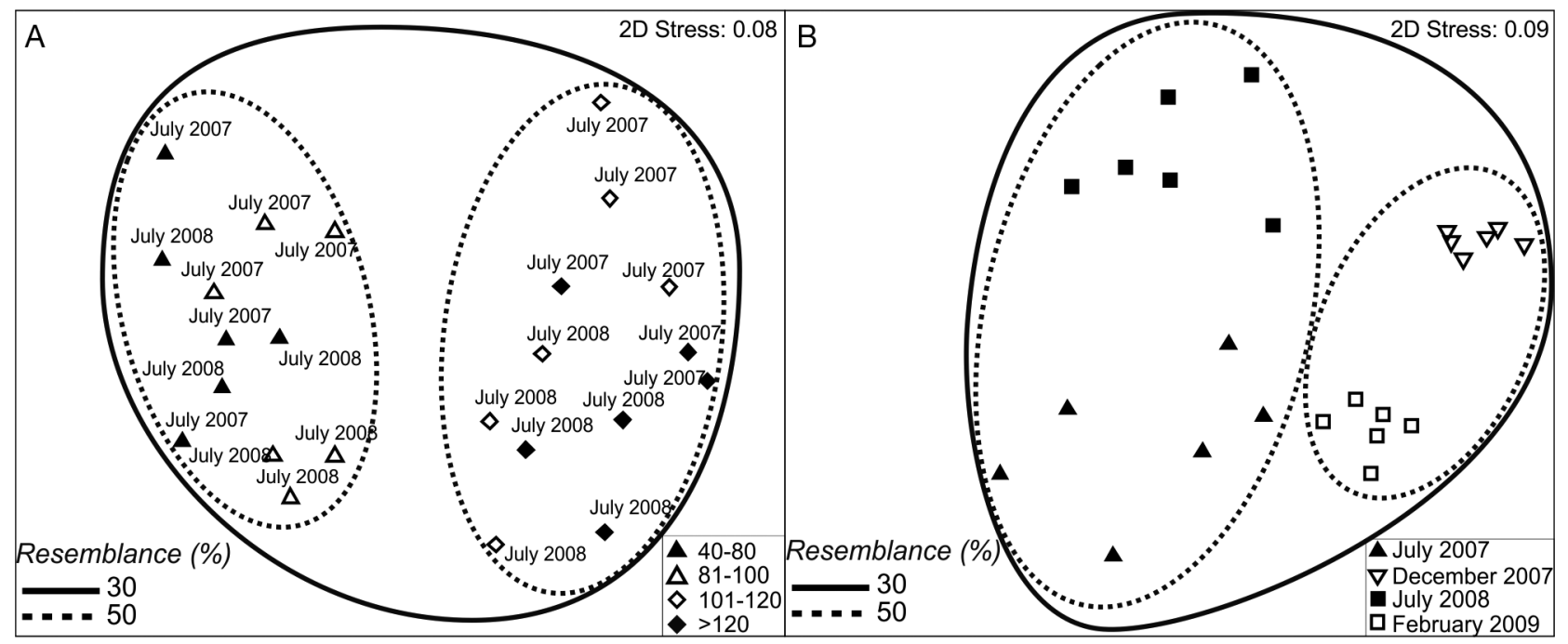

Fig. 1. Multi-dimensional scaling ordination plots of (A) the samples used to analyze sardine diet in summer (July 2007 and July 2008) with symbols denoting different size classes (in $\mathrm{mm}$ ), and (B) the samples of adult (>100 mm) sardines with symbols denoting sampling periods. Groups defined by the respective cluster analyses (at $30 \%$ and $50 \%$ resemblance levels) are also indicated 


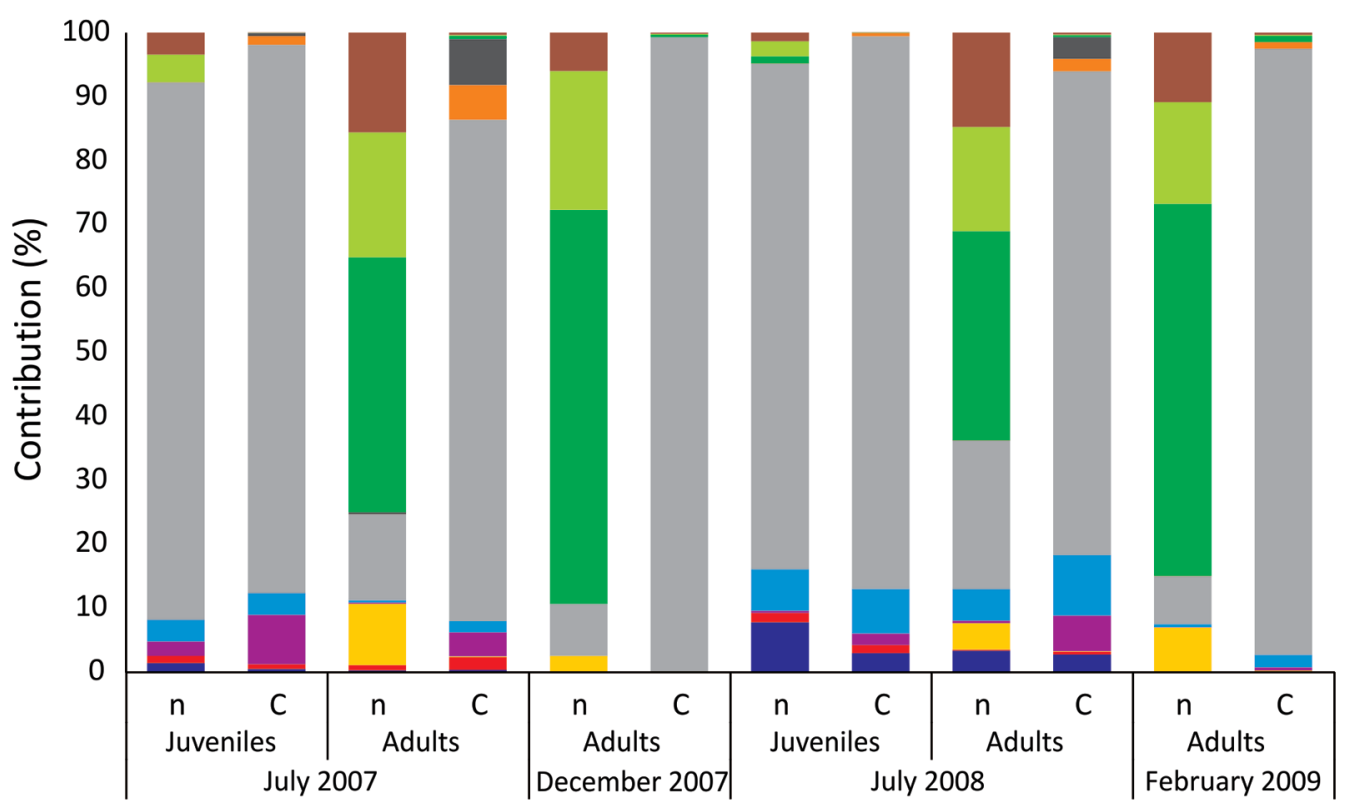

Dinoflagellates (heterotrophic)

Dinoflagellates (autotrophic)

Diatoms

Gastropods

Decapods

Copepods

Cladocerans

Cirripedes

Ciliates

Bivalves

Appendicularians

Fig. 2. Percentages of prey categories per fish stomach in terms of (n) numbers and $(\mathrm{C})$ dietary carbon

Table 2. Ivlev's selectivity index for mesozooplankton taxa with $>1 \%$ numerical contribution to sardine diet. Values $\leq-0.5$ or $\geq 0.5$ in bold

\begin{tabular}{|c|c|c|c|c|c|c|}
\hline \multirow[t]{2}{*}{ Taxon } & \multicolumn{2}{|c|}{ — July 2007} & \multirow{2}{*}{$\begin{array}{c}\text { December } 2007 \\
\text { Adults }\end{array}$} & \multicolumn{2}{|c|}{ July $2008-$} & \multirow{2}{*}{$\begin{array}{c}\text { February } 2009 \\
\text { Adults }\end{array}$} \\
\hline & Juveniles & Adults & & Juveniles & Adults & \\
\hline Acartia clausi & 0.734 & 0.623 & 0.045 & 0.120 & -0.477 & -0.288 \\
\hline Appendicularians & -0.756 & -0.711 & & 0.185 & 0.353 & \\
\hline Calanus spp. & & & & & & 0.097 \\
\hline Centropages spp. & 0.141 & -0.082 & 0.834 & 0.034 & 0.067 & 0.196 \\
\hline Cirriped larvae & 0.952 & & & & 0.829 & \\
\hline Clytemnestra spp. & & 0.986 & & 0.956 & 0.970 & \\
\hline Copepod nauplii & 0.894 & & & 0.699 & 0.663 & \\
\hline Corycaeidae & 0.264 & 0.722 & & 0.870 & 0.874 & 0.587 \\
\hline Euterpina acutifrons & 0.971 & 0.935 & & 0.967 & 0.963 & \\
\hline Evadne spinifera & & & & & -0.773 & \\
\hline Gastropod larvae & & 0.539 & & & & \\
\hline Harpacticoids & & 0.877 & & & & \\
\hline Lamellibranchia larvae & 0.881 & 0.966 & & 0.741 & & \\
\hline Microsetella rosea & 0.982 & 0.976 & & 0.950 & 0.978 & \\
\hline Oithona spp. & 0.151 & 0.330 & -0.437 & 0.073 & -0.230 & \\
\hline Oncaea spp. & 0.881 & 0.802 & 0.201 & 0.953 & 0.942 & 0.761 \\
\hline Clauso-Paracalanidae & -0.601 & -0.467 & -0.797 & -0.699 & -0.677 & -0.043 \\
\hline Penilia avirostris & & & & -0.793 & -0.625 & \\
\hline Podon spp. & 0.559 & 0.293 & & 0.714 & 0.709 & 0.755 \\
\hline Pseudoevadne tergestina & & & & & -0.066 & \\
\hline Temora stylifera & 0.612 & 0.764 & 0.375 & 0.45 & 0.466 & \\
\hline
\end{tabular}

Table S2 for all prey taxa), the diet overlap was quite high $\left(S_{(\text {C) July 2007 }}=0.73, S_{(\text {C) July } 2008}=0.86\right)$. In terms of carbon content, the calanoids A. clausi, T. stylifera, Centropages spp. and the group Clauso-Paracalanidae were important prey items for both juveniles and adults in summer (Table S2).

For adult sardines (Fig. 1B), the major differentiation in the diet was between the stratified (July 2007 and July 2008) and mixed (December 2007 and Feb- ruary 2009) periods. The PERMANOVA ( $F=16.024$, $\mathrm{p}=0.0001$ ) and subsequent pair-wise comparisons revealed significant differences in the diet composition between all sampling periods (Table 1). The SIMPER analysis showed that the differences in the diet were due to both copepod species (mainly Acartia clausi, Oncaea spp., Euterpina acutifrons, Temora stylifera and Centropages spp.) and phytoplankton genera (Chaetoceros, Pseudo-nitzschia and Neo- 
ceratium) (see Table S4 in the supplement). In the mixing periods, the phytoplankton numerical contribution was higher (average: $78 \%$ ) than in the stratification periods (average: $54 \%$ ) (Fig. 2, Table S2). Copepods contributed less to dietary carbon in the stratification periods $(76.5 \%)$ than in the mixing periods $(97.4 \%)$. In stratified conditions, other zooplankton groups also contributed considerably to the dietary carbon (e.g. cladocerans and gastropod larvae) (Fig. 2, Table S2). The most important copepods in terms of carbon were the relatively large calanoid copepods (A. clausi, T. stylifera and Centropages typicus) (Table S2). There was strong overlap in the diet of adult sardines between July 2007 and July 2008 and between December 2007 and February $2009\left(S_{(\mathrm{C})}>0.67\right)$, in contrast to low overlap $(<0.33)$ between any stratification vs. mixing period comparison (e.g. $\left.S_{(\mathrm{CC}) \text { Jul 2007-Dec 2007 }}=0.19\right)$. Furthermore, Ivlev's selectivity index $(E)$ was highly positive for many more species in July than in December/ February (Table 2). The most abundant copepod group (Clauso-Paracalanidae) always had very low $E$ values, except in February 2009, implying avoidance and/or low catchability of this prey (Table 2). The diversity $\left(H^{\prime}\right)$ of copepods and cladocerans in the stomachs of adults was higher in the stratified periods than in the mixing periods $(F=31.12$, p < 0.0001).

\section{Ambient environment}

The means of the sampled biotic and abiotic variables and significant differences between sampling periods are presented in Table 3. The main trophic pathways in the pelagic ecosystem (Siokou-Frangou et al. 2010) are summarized in Fig. 3, while temperature and salinity profiles as well as variability of the selected variables are summarized in Figs. 4 \& 5, respectively. In July 2007 and July 2008, stratification was intense, whereas in December 2007, the water column was mixed but significantly warmer than in February 2009 (Fig. 4, Table 4A). Levels of dissolved inorganic phosphorus and nitrogen were lower in

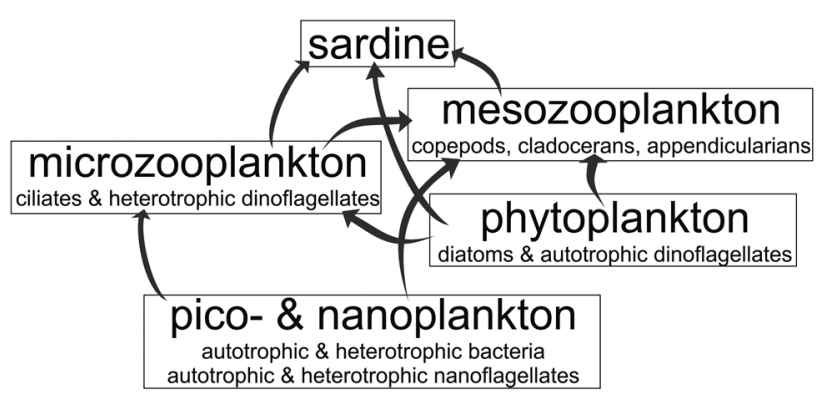

Fig. 3. Main components of the pelagic food web with arrows indicating the major trophic flows. Note that the size of arrows does not quantify energy flow

Table 3. Comparison of physical and biotic variables between sampling periods. Arithmetic means and F-values are provided except for comparisons that did not meet the assumptions of the analysis of variance for which medians and the Kruskal-Wallis statistic $(H)$ are given. For non-parametric tests, medians are shown. ${ }^{*} \mathrm{p}<0.05,{ }^{* *} \mathrm{p}<0.01,{ }^{* * *} \mathrm{p}<0.001$, $a>b>c>d$ Homogenous groups

\begin{tabular}{|c|c|c|c|c|c|}
\hline & July 2007 & December 2007 & July 2008 & February 2009 & Statistic \\
\hline Heterotrophic bacteria $\left(\times 10^{11}\right.$ cells m$\left.^{-3}\right)$ & $14.82^{\mathrm{a}}$ & $6.96^{\mathrm{b}}$ & $2.31^{\mathrm{c}}$ & $6.96^{\mathrm{b}}$ & $F=1694.18^{* * *}$ \\
\hline Autotrophic bacteria $\left(\times 10^{10}\right.$ cells $\left.\mathrm{m}^{-3}\right)$ & $3.48^{\mathrm{b}}$ & $0.894^{\mathrm{d}}$ & $1.56^{\mathrm{c}}$ & $4.02^{\mathrm{a}}$ & $F=590.36^{* * *}$ \\
\hline Autotrophic nanoflagellates $\left(\times 10^{8}\right.$ cells $\left.\mathrm{m}^{-3}\right)$ & $19.01^{\mathrm{b}}$ & $69.45^{\mathrm{a}}$ & $9.44^{\mathrm{c}}$ & $5.25^{\mathrm{d}}$ & $F=121.56^{* * *}$ \\
\hline Heterotrophic nanoflagellates $\left(\times 10^{8}\right.$ cells $\left.\mathrm{m}^{-3}\right)$ & $22.43^{\mathrm{a}}$ & $14.50^{\mathrm{b}}$ & $18.50^{\mathrm{a}, \mathrm{b}}$ & $6.33^{\mathrm{c}}$ & $F=36.13^{* * *}$ \\
\hline Ciliates $\left(\times 10^{6}\right.$ cells m $\left.\mathrm{s}^{-3}\right)$ & $0.170^{\mathrm{c}}$ & $1.57^{\mathrm{a}}$ & $0.276^{\mathrm{b}}$ & $1.51^{\mathrm{a}}$ & $F=131.38^{* * *}$ \\
\hline Diatoms $\left(\times 10^{6}\right.$ cells m $\left.{ }^{-3}\right)$ & $0.484^{\mathrm{d}}$ & $134.18^{\mathrm{a}}$ & $1.58^{\mathrm{c}}$ & $65.77^{\mathrm{b}}$ & $F=448.76^{* * *}$ \\
\hline Heterotrophic dinoflagellates $\left(\times 10^{5}\right.$ cells $\left.\mathrm{m}^{-3}\right)$ & $0.533^{\mathrm{b}}$ & $6.07^{\mathrm{a}}$ & $0.677^{\mathrm{b}}$ & $5.70^{\mathrm{a}}$ & $F=56.52^{* * *}$ \\
\hline Autotrophic dinoflagellates $\left(\times 10^{5}\right.$ cells $\left.\mathrm{m}^{-3}\right)$ & $0.870^{\mathrm{b}}$ & $1.53^{\mathrm{b}}$ & $1.62^{\mathrm{b}}$ & $3.87^{\mathrm{a}}$ & $F=13.70^{* *}$ \\
\hline Copepod nauplii $\left(\times 10^{3}\right.$ cells $\left.\mathrm{m}^{-3}\right)$ & $9.46^{\mathrm{b}}$ & $8.38^{\mathrm{a}, \mathrm{b}}$ & $15.61^{\mathrm{a}, \mathrm{b}}$ & $17.20^{\mathrm{a}}$ & $F=6.84^{*}$ \\
\hline Copepods $\left(\times 10^{3}\right.$ cells $\left.\mathrm{m}^{-3}\right)$ & $2.17^{\mathrm{a}}$ & $1.59^{\mathrm{a}, \mathrm{b}}$ & $1.08^{\mathrm{b}}$ & $1.04^{\mathrm{b}}$ & $F=7.40^{*}$ \\
\hline Appendicularians (cells $\mathrm{m}^{-3}$ ) & $137.89^{\mathrm{a}, \mathrm{b}}$ & $218.41^{\mathrm{a}}$ & $237.82^{\mathrm{a}}$ & $35.73^{\mathrm{b}}$ & $F=7.03^{*}$ \\
\hline Cladocerans $\left(\times 10^{3}\right.$ cells $\left.\mathrm{m}^{-3}\right)$ & $0.333^{\mathrm{b}}$ & $0.247^{\mathrm{b}}$ & $1.47^{\mathrm{a}}$ & $0.005^{\mathrm{c}}$ & $F=49.51^{* * *}$ \\
\hline Mean chl $a$ in the water column $\left(\mu \mathrm{gl}^{-1}\right)$ & $0.140^{\mathrm{c}}$ & $1.36^{\mathrm{a}}$ & $0.126^{\mathrm{c}}$ & $0.758^{\mathrm{b}}$ & $F=98.89^{* * *}$ \\
\hline Mean temperature in the water column $\left({ }^{\circ} \mathrm{C}\right)$ & $17.86^{\mathrm{a}}$ & $14.72^{\mathrm{b}}$ & $18.90^{\mathrm{a}}$ & $11.36^{\mathrm{c}}$ & $H=90.00^{* * *}$ \\
\hline Mean salinity in the water column & 38.02 & 37.18 & 37.85 & 36.74 & $H=5.30$ \\
\hline Mesozooplankton biomass $\left(\mathrm{mg} \mathrm{m}^{-3}\right.$ ) & $29.02^{\mathrm{b}}$ & $36.40^{\mathrm{a}}$ & $24.70^{\mathrm{b}}$ & $28.05^{\mathrm{b}}$ & $F=7.54^{* * *}$ \\
\hline Microplankton biomass $\left(\mathrm{mg} \mathrm{m}^{-3}\right)$ & $32.18^{\mathrm{c}}$ & $91.04^{\mathrm{b}}$ & $22.70^{\mathrm{c}}$ & $130.73^{\mathrm{a}}$ & $F=76.43^{* * *}$ \\
\hline $\mathrm{P}\left(\mathrm{PO}_{4}{ }^{3-}\right)(\mu \mathrm{M})$ & $0.035^{\mathrm{b}}$ & $0.088^{\mathrm{a}}$ & $0.017^{\mathrm{b}}$ & $0.075^{\mathrm{a}}$ & $F=13.74^{* *}$ \\
\hline $\mathrm{Si}\left(\mathrm{SiO}_{2}\right)(\mu \mathrm{M})$ & $3.30^{\mathrm{a}}$ & $4.17^{\mathrm{a}}$ & $3.08^{\mathrm{a}}$ & $1.25^{\mathrm{b}}$ & $F=14.15^{* *}$ \\
\hline $\mathrm{N}\left(\mathrm{NO}_{2}^{-}+\mathrm{NO}_{3}^{-}\right)(\mu \mathrm{M})$ & $0.370^{\mathrm{b}}$ & $2.28^{\mathrm{a}}$ & $0.821^{\mathrm{b}}$ & $2.15^{\mathrm{a}}$ & $F=27.46^{* * *}$ \\
\hline
\end{tabular}


Temperature $\left({ }^{\circ} \mathrm{C}\right)$

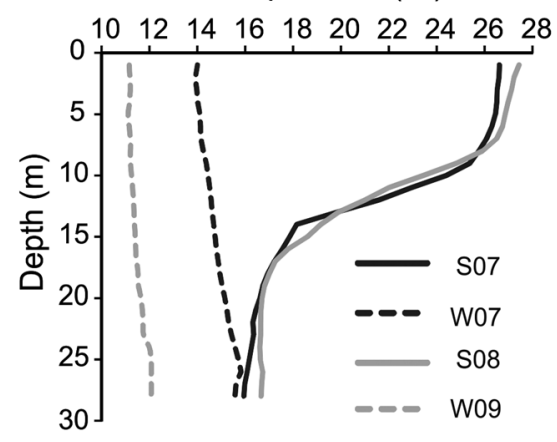

Salinity

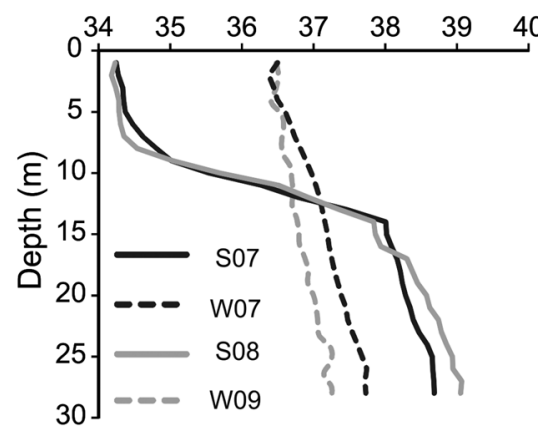

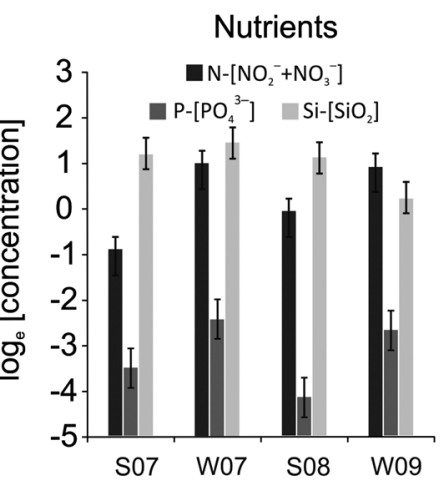

Chl a

Fig. 4. Vertical profiles of temperature and salinity (left) and mean values and $95 \%$ Bonferroni-corrected confidence intervals of dissolved inorganic nutrients and chl a (right) during the 4 sampling periods. S07: July 2007. W07: December 2007. S08: July 2008. W09: February 2009

both stratified periods than in the mixing periods (Fig. 4, Table 3). Silicate concentrations were significantly lower in only February 2009 (Fig. 4, Table 3). Chl a was significantly higher in the mixing periods largely due to the high abundance of diatoms (Pearson correlation coefficient between $\mathrm{chl} a$ and diatom abundance: $r=0.999, p<0.0001$ ) (Fig. 5). The abundance of ADs was significantly lower in February 2009 (Fig. 5). Pico- and nanoplankton abundances did not exhibit common patterns of variation or consistent trends between the stratified and mixing periods (Fig. 5, Table 3). The abundances of ciliates and heterotrophic dinoflagellates (microzooplankton) were significantly higher during the mixing periods. Copepods were always the dominant group in the mesozooplankton collections (Table 4), with abundances ranging from 1040 (February 2009) to 2170 (July 2007) individuals $\mathrm{m}^{-3}$ (Fig. 5, Table 3). The inverse pattern was observed for copepod nauplii. The abundance of cladocerans and appendicularians was higher in summer but also significantly higher in December (war-
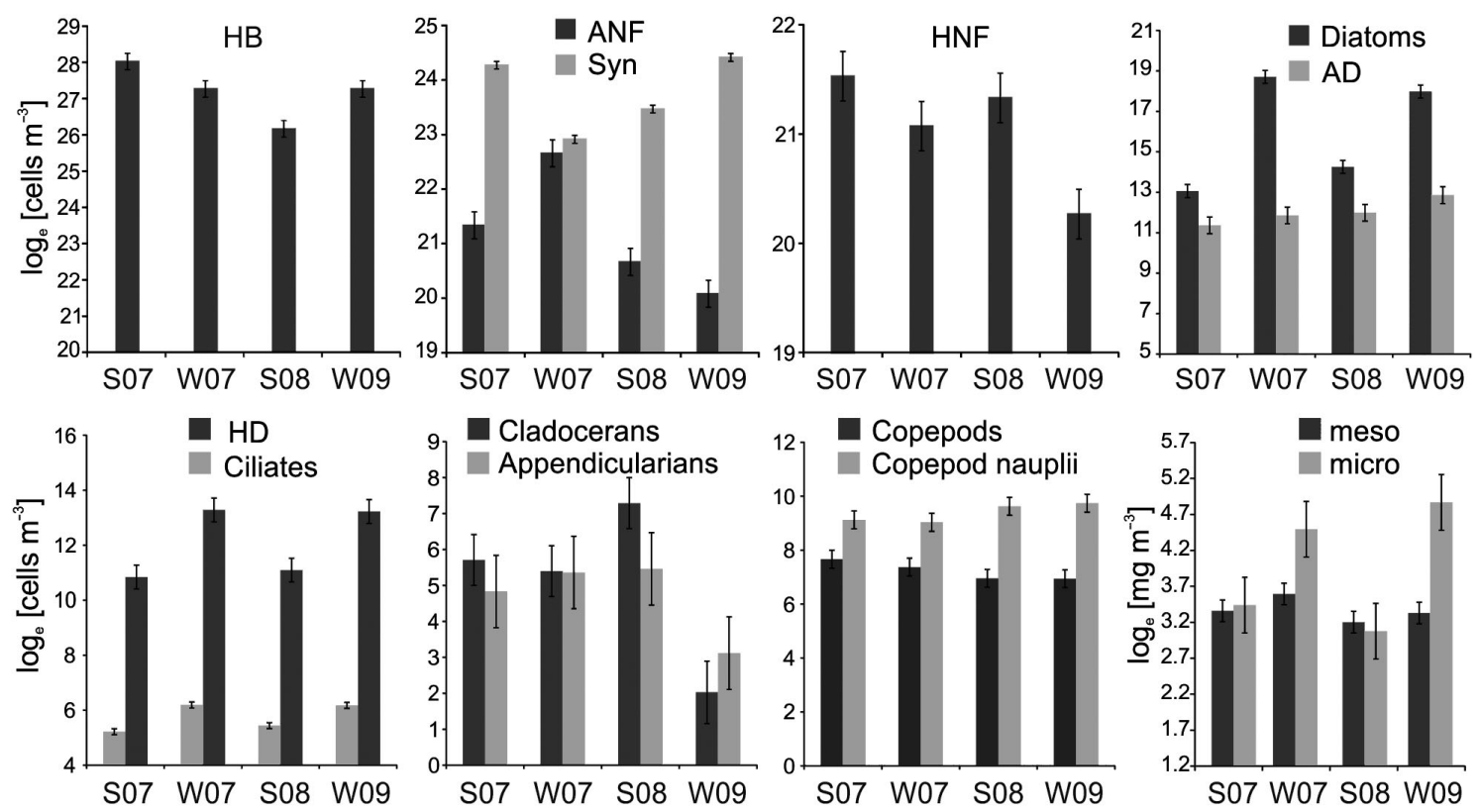

Fig. 5. Mean values and 95\% Bonferroni-corrected confidence intervals of selected biotic variables measured during the 4 sampling periods. HB: heterotrophic bacteria. Syn: Synechococcus (autotrophic bacteria). ANF: autotrophic nanoflagellates. HNF: heterotrophic nanoflagellates. AD: autotrophic dinoflagellates. HD: heterotrophic dinoflagelates. meso: mesozooplankton biomass. micro: microzooplankton biomass. S07: July 2007. W07: December 2007. S08: July 2008. W09: 
Table 4. Field-collected mesozooplankton samples. Numerical contribution (\%) of major groups

\begin{tabular}{|lcccc|}
\hline Group & July & $\begin{array}{c}\text { December } \\
2007\end{array}$ & $\begin{array}{c}\text { July } \\
2008\end{array}$ & $\begin{array}{c}\text { February } \\
2009\end{array}$ \\
\hline Amphipods & 0.06 & 0 & 0.08 & 0 \\
Appendicularians & 7.90 & 3.47 & 5.45 & 0.25 \\
Chaetognaths & 0.73 & 2.40 & 0.54 & 0.25 \\
Cirriped larvae & 0.03 & 0.96 & 0.11 & 0.18 \\
Cladocerans & 24.81 & 7.12 & 35.54 & 1.10 \\
Copepods & 63.43 & 80.57 & 54.34 & 96.07 \\
Decapod larvae & 0.31 & 0.32 & 0.26 & 0.08 \\
Doliolids & 1.47 & 1.24 & 0.75 & 0.32 \\
Echinoderm larvae & 0.14 & 1.12 & 0.04 & 0.05 \\
Euphausiids & 0.10 & 0.03 & 0.02 & 0.01 \\
Gastropod larvae & 0.45 & 0.59 & 2.35 & 0.69 \\
Isopods & 0.01 & 0.02 & 0 & 0 \\
Lamellibranchia & 0.08 & 0.07 & 0.22 & 0.16 \\
larvae & & & & \\
Medusae & 0.18 & 0.32 & 0.12 & 0.47 \\
Mysids & 0 & $<0.01$ & 0 & 0 \\
Ostracods & 0 & 0.2 & 0 & 0.08 \\
Polychaete larvae & 0.03 & 1.35 & 0.05 & 0.17 \\
Pteropods & 0.26 & 0.18 & 0.11 & 0.04 \\
Siphonophores & 0.01 & 0.04 & 0.02 & 0.08 \\
\hline
\end{tabular}

mer waters) than in February (Fig. 5, Tables 3 \& 4). Finally, mesozooplankton biomass was significantly higher in December 2007 compared to other sampling periods, whereas microplankton biomass was significantly higher in both mixing periods in relation to the stratified periods (Fig. 5, Table 3).

The Clauso-Paracalanidae was always the most abundant copepod group in the field (Fig. S1 in the supplement), especially in the summer periods. In February 2009, however, the large calanoid copepod Centropages typicus had similar abundances ( 30\%) to the Clauso-Paracalanidae group (Fig. S1). Other abundant copepods were the calanoids Temora stylifera and Acartia clausi in summer and Oithona spp. and copepodites of Calanus spp. in the mixing periods (Fig. S1). Regarding cladocerans, the abundance of Penilia avirostris was very high in summer, followed by Evadne spinifera and Pseudoevadne tergestina (Fig. S1).

\section{Field and prey size frequency distributions}

Adult sardines retained smaller particles than juveniles in both summers (Table 5). When the numerical contribution of prey was considered, adults exhibited 2 modes (1-200 $\mu \mathrm{m}$ and 401-1000 $\mu \mathrm{m}$ ), with the 1-200 $\mu \mathrm{m}$ class important in all sampling periods (Table 5). This class corresponded to diatoms, dinoflagellates, ciliates and nauplii of copepods, whereas the 401 to $1000 \mu \mathrm{m}$ range comprised small- and medium-sized copepods, cladocerans, cirriped nauplii, gastropod larvae and pteropods (see Table S1 in the supplement). The numerical frequency distributions in juveniles exhibited 2 main modes (401-600 $\mu \mathrm{m}$ and 801-1000 $\mu \mathrm{m}$ ) as well. In terms of carbon, however, the 801 to $1000 \mu \mathrm{m}$ size class contributed the most for both juveniles and adults in July $\left(\sim 48\right.$ to $\left.57 \%_{C}\right)$ and was dominated by the calanoid copepods Temora stylifera and Acartia clausi. Smaller size classes (401-600 and 601-800 $\mu \mathrm{m}$ ) also had some contribution to dietary carbon, owed to smaller copepods (Euterpina acutifrons, Oncaea spp. and Clauso-Paracalanidae) as well as gastropod and cirriped larvae (for mean prey sizes, see Table S1).

The differences between the numerical and the carbon contributions were striking in the mixing

Table 5. Numerical $\left(\%_{n}\right)$ and carbon $\left(\%_{C}\right)$ contribution to diet per size-class of prey

\begin{tabular}{|c|c|c|c|c|c|c|c|c|c|c|c|c|}
\hline \multirow{3}{*}{$\begin{array}{l}\text { Size-class } \\
(\mu \mathrm{m})\end{array}$} & \multicolumn{4}{|c|}{ — July 2007} & \multirow{2}{*}{\multicolumn{2}{|c|}{$\begin{array}{l}\text { December } 2007 \\
\text { Adults }\end{array}$}} & \multicolumn{4}{|c|}{ — July 2008} & \multirow{2}{*}{\multicolumn{2}{|c|}{$\begin{array}{c}\text { February } 2009 \\
\text { Adults }\end{array}$}} \\
\hline & \multicolumn{2}{|c|}{ Juveniles } & \multicolumn{2}{|c|}{ Adults } & & & \multicolumn{2}{|c|}{ Juveniles } & \multicolumn{2}{|c|}{ Adults } & & \\
\hline & $\%_{n}$ & $\%_{\mathrm{C}}$ & $\%_{\mathrm{n}}$ & $\%_{\mathrm{C}}$ & $\%_{n}$ & $\%_{\mathrm{C}}$ & $\%_{\mathrm{n}}$ & $\%_{\mathrm{C}}$ & $\%_{n}$ & $\%_{\mathrm{C}}$ & $\%_{\mathrm{n}}$ & $\%_{\mathrm{C}}$ \\
\hline $1-200$ & 10.25 & 0.26 & 77.99 & 1.04 & 87.59 & 0.38 & 12.02 & 0.76 & 68.24 & 1.17 & 76.32 & 0.79 \\
\hline $201-400$ & 2.19 & 0.82 & 0.95 & 1.87 & 0 & 0 & 8.84 & 2.97 & 3.87 & 3.14 & 0 & 0 \\
\hline $401-600$ & 35.37 & 16.01 & 4.17 & 14.05 & 0.46 & 0.42 & 42.85 & 18.49 & 15.4 & 21.83 & 1.01 & 2.15 \\
\hline $601-800$ & 15.9 & 12.78 & 10.05 & 13.35 & 4.6 & 1.3 & 10.89 & 10.89 & 6.06 & 15.07 & 18.33 & 12.83 \\
\hline $801-1000$ & 31.78 & 50.58 & 6.34 & 57.43 & 0.99 & 8.7 & 23.69 & 55.71 & 5.88 & 48.23 & 0.53 & 2.28 \\
\hline $1001-1200$ & 4.49 & 17.67 & 0.49 & 8.55 & 5.93 & 76.96 & 1.35 & 6.77 & 0.5 & 6.91 & 3.7 & 77.18 \\
\hline $1201-1400$ & 0 & 0 & 0 & 0 & 0.34 & 8.86 & 0.35 & 3.57 & 0.04 & 1.11 & 0.09 & 3.86 \\
\hline $1401-1600$ & 0.01 & 0.21 & 0 & 0.3 & 0.04 & 1.1 & 0 & 0.16 & 0 & 0.23 & 0.01 & 0.37 \\
\hline $1601-1800$ & 0 & 0 & 0 & 0 & 0.03 & 0.23 & 0 & 0 & 0 & 0 & 0 & 0 \\
\hline $1801-2000$ & 0 & 0 & 0 & 0 & 0.02 & 2.05 & 0 & 0 & 0 & 0 & 0 & 0 \\
\hline $2001-2200$ & 0.01 & 1.67 & 0.01 & 3.41 & 0 & 0 & 0.01 & 0.68 & 0.01 & 2.31 & 0.01 & 0.54 \\
\hline
\end{tabular}


periods (Table 5). The numerical contribution of the 1-200 $\mu \mathrm{m}$ size class (mainly phytoplankton) was on average $78 \%$ (Table 5), whereas that of copepods was $\sim 8 \%$. In both mixing periods, however, the bulk of the dietary carbon was from the 1001-1200 $\mu \mathrm{m}$ size class $(\sim 77 \%$, Table 5$)$, i.e. the calanoid copepod Centropages typicus. Finally, the contribution of the largest size class $(>2000 \mu \mathrm{m})$, i.e. decapod larvae, was always low $\left(<3.5 \%_{C}\right.$, Table 5$)$.

The comparison of the size frequency distributions of copepods and cladocerans between the field and the stomachs of adult sardines showed a broad overlap in both summers, in terms of both numerical abundance and carbon (Fig. 6). In both July 2007 and 2008, the 801-1000 $\mu \mathrm{m}$ class accounted for 55 to $70 \%$ of the dietary carbon, whereas in the field, the main carboncontributing size class was the 601-800 $\mu \mathrm{m}$ class. In December 2007 and February 2009, the size frequency distributions exhibited smaller overlaps, and the bulk of dietary carbon derived from the 1001-1200 $\mu \mathrm{m}$ class.

\section{Reflections of food web structure in sardine diets}

In July 2007 and 2008, the carbon budget of autotrophic cells $<20 \mu \mathrm{m}$ was 13 - to 15 -fold higher than that of the $>20 \mu \mathrm{m}$ cells (mainly diatoms and ADs) (Fig. 7A). In February 2009, when the water column was mixed and the temperature was lower than in other sampling periods, large phytoplankters $(>20 \mu \mathrm{m})$ dominated the study area, and the carbon content of diatoms and ADs was $\sim 60$-fold higher than that of autotrophic pico- and nanoplankton (Fig. 7A). In December 2007, with mixed but warmer waters (the initial phase of the mixing period), the carbon ratio of autotrophs $>20 \mu \mathrm{m}$ to $<20 \mu \mathrm{m}$ was 1.2 (Fig. 7A). Furthermore, the carbon ratio of the autotrophic (Syn and ANF) to heterotrophic (HB and HNF) pico- and nanoplankton communities was $<1$ in both summers $(0.439$ and 0.472 in July 2007 and July 2008, respectively), whereas this ratio was 2.07 and 0.828 in December 2007 and February 2009, respectively.

When compared to summers, the difference in the weighted mean size of copepods and cladocerans between the stomachs of adults and the field samples was larger in the mixing periods (Fig. 6). The carbon-based copepod and cladoceran mean size in the field (size field $_{\text {) }}$ was highly correlated with the density of diatoms (Fig. 7B), implying that the prevalence of the classical food chain could be an important factor regulating the weighted mean size of the mesozooplankton community. When larger prey organisms were more abundant in the field, this was reflected in the diet of adult sardines (Fig. 7C). Furthermore, there was a negative relationship between mesozooplankton prey diversity in the stomachs and average prey size (Fig. 7D).
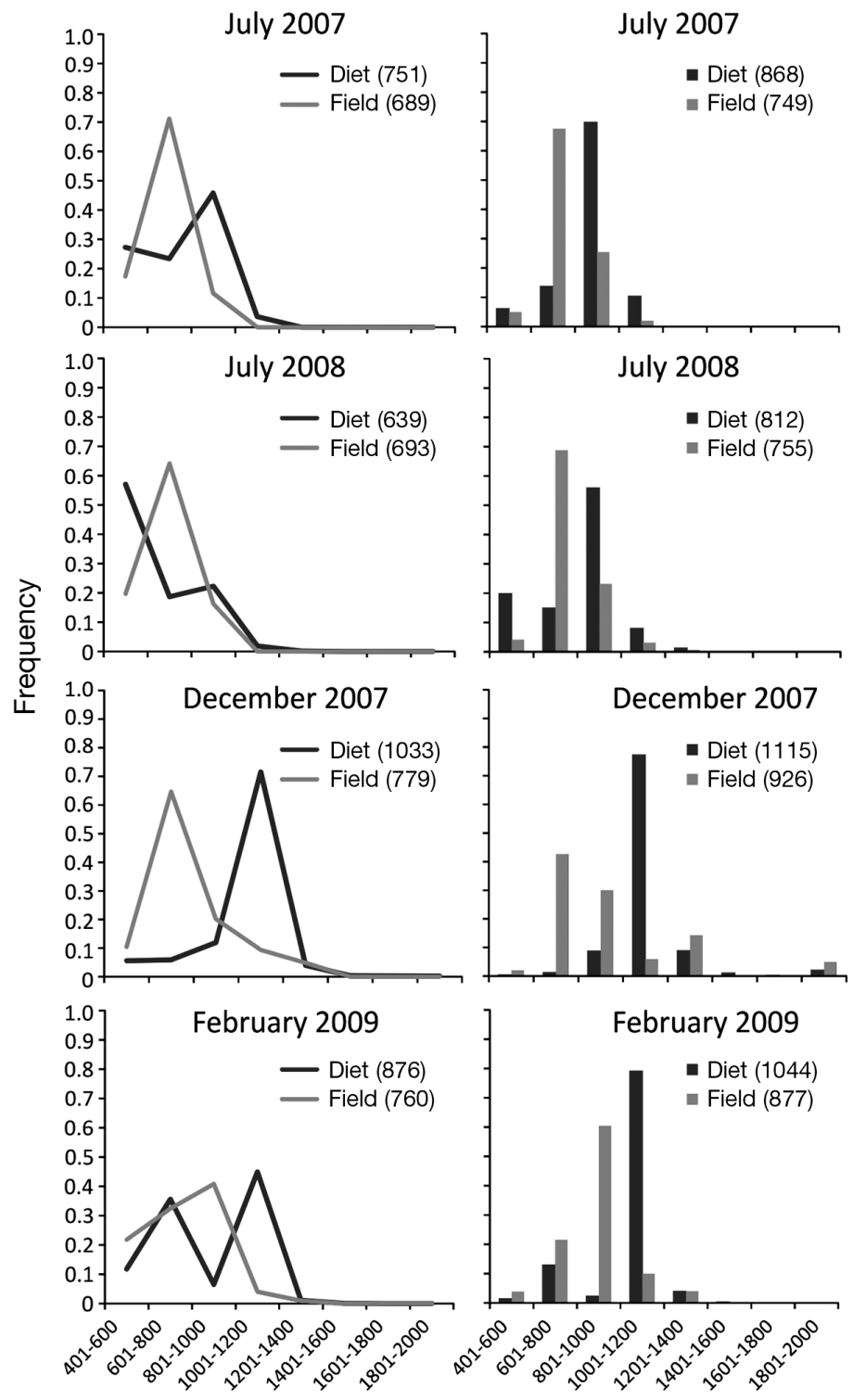

Size $(\mu \mathrm{m})$

Fig. 6. Size-frequency distribution of copepods and cladocerans in the stomachs and the field in terms of (lines) numbers and (bars) dietary carbon. Weighted mean sizes in the diet and the field (in $\mu \mathrm{m}$ ) are shown in parentheses 

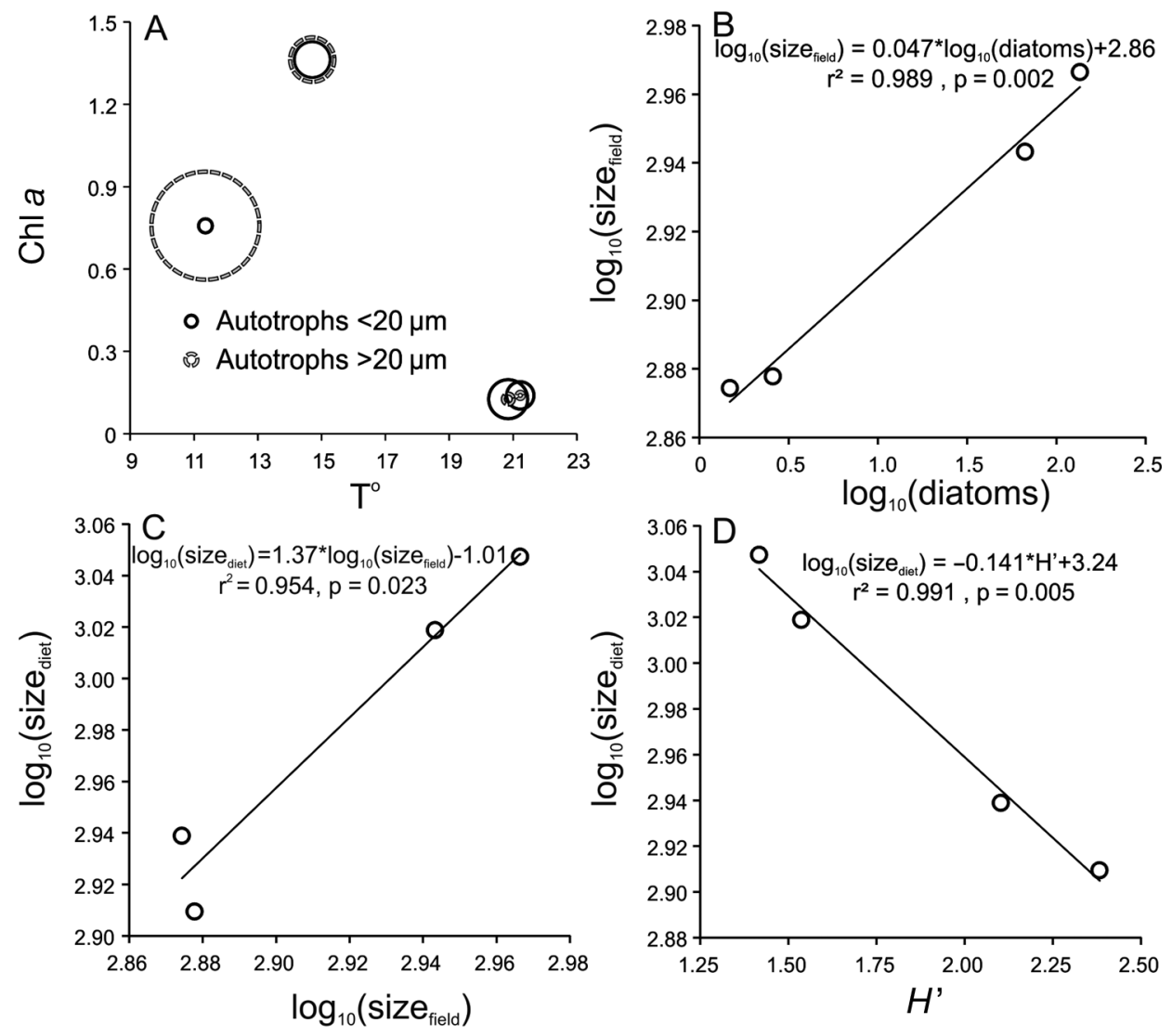

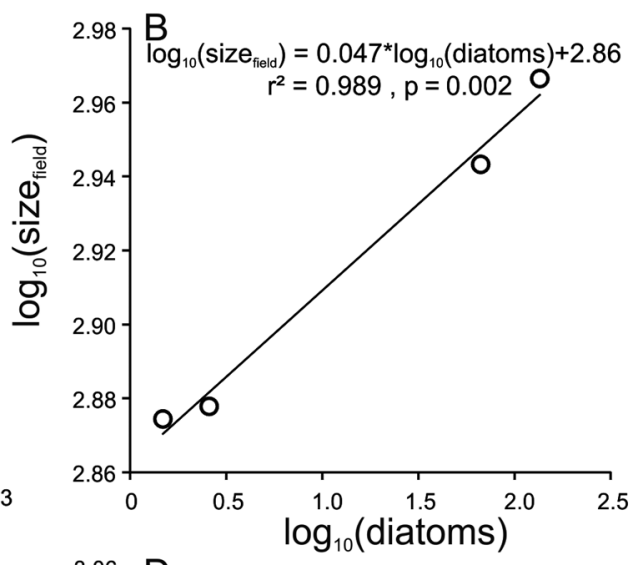

Fig. 7. (A) Carbon content of the autotrophic community $>20 \mu \mathrm{m}$ and $<20 \mu \mathrm{m}$ in relation to chl $a$ and (T) temperature. Area of circles is proportional to carbon content (area of circle in legend corresponds to $5 \mathrm{mg} \mathrm{C} \mathrm{m}^{-3}$ ). (B) Relationship between diatom concentration (cells $\mathrm{m}^{-3}$ ) and carbon-based weighted mean size of copepods and cladocerans in the field size $_{\text {field }}$ $\mu \mathrm{m})$. (C) Relationship between size field $_{\text {and }}$ carbonbased weighted mean size

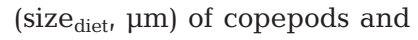
cladocerans in the stomachs of adult sardines. (D) Relationship between size $_{\text {diet }}$ and the Shannon-Wiener diversity index $\left(H^{\prime}\right)$ of copepods and cladocerans in the stomachs of adult sardines

\section{DISCUSSION}

\section{Sardine diet}

In a number of studies regarding sardine diet in which the ambient environment has been sampled concurrently, it has been argued that sardines are essentially filter-feeders with diets reflecting local plankton compositions (e.g. Garrido et al. 2008a, van der Lingen et al. 2009). This is largely due to the nonselective filtering mechanism that retains prey according to size rather than type. Laboratory studies of Sardinops sagax (van der Lingen 1994) and Sardina pilchardus (Garrido et al. 2007a) have shown that sardines are capable of retaining even nanoplankton prey $(<20 \mu \mathrm{m})$. This ability is attributed to their numerous elongated gill rakers which, combined with the miniature denticles that grow unidirectionally, aligned along the entire gill raker length, equip sardines with a very fine filtering apparatus (Andreu 1969, King \& Macleod 1976). Filtration, however, is not the only feeding mode. S. sagax is known to switch from filter to particulate feeding at a prey size of $1230 \mu \mathrm{m}$ (van der Lingen 1994), whereas switching to particulate feeding occurs at a smaller prey size in Sardina pilchardus from the Atlantic (filter feeding on prey $<724 \mu \mathrm{m}$ and particulate feeding on prey $>780 \mu \mathrm{m}$ ) (Garrido et al. 2007a). Apart from prey size, another important difference between these 2 species is that, when large prey is encountered, the feeding mode employed is controlled by prey density in S. sagax (van der Lingen 1994) but not in S. pilchardus (Garrido et al. 2007a).

The role of zooplankton, and particularly copepods, in sardine diets has been emphasized in many studies, including upwelling and non-upwelling systems (e.g. van der Lingen 2002, Garrido et al. 2008a, Espinoza et al. 2009, the present study). Calanoid copepods of the genera Acartia, Temora and Centropages comprise the main source of dietary carbon, with secondary contributions from cyclopoid (e.g. Oncaea spp.) and harpacticoid (e.g. Euterpina acutifrons) copepods (Cunha et al. 2005, Garrido et al. 2008a). Other zooplankton groups (e.g. decapod, gastropod and cirriped larvae) also contribute to dietary carbon of Sardina pilchardus in both the Atlantic (Garrido et al. 2008a) and the Mediterranean (present study). In the western Mediterranean and adjacent Atlantic waters, however, the contribution of cladocerans and appendicularians has been repor- 
ted as insignificant (Massuti \& Oliver 1948, Varela et al. 1990, Garrido et al. 2008a), which is in contrast to our findings in the eastern Mediterranean. Additionally, fish eggs were not detected in our samples, whereas in the Atlantic, their contribution on an annual basis ranged from 17.4 to $30 \%$ of the total dietary carbon. The absence of fish eggs in sardine stomachs could be explained by the very low numbers of eggs in the water column $(<0.005 \%$ in the plankton samples) at the shallow sampling site of the present study. The preference for zooplankton has also been verified by isotopic studies showing that most of the nitrogen-forming structural muscle proteins in adults originate from the assimilation of zooplankton, while only a small portion of carbon could be derived from phytoplankton (Bode et al. 2004).

The contribution of phytoplankton to the dietary carbon of adult sardines in the North Aegean Sea was trivial (always $<3 \%$ in all samples examined) although phytoplankton were numerically dominant in the stomachs. Adult sardines worldwide ingest large numbers of phytoplankton cells (van der Lingen et al. 2009), which led to the characterization of sardines as phytoplanktophagous in the past (e.g. King \& Macleod 1976). This conclusion was, however, erroneous and resulted from the use of numerical or frequency-of-occurrence data that bias results in favor of small, abundant prey (James 1987). This view changed dramatically when prey importance was assessed in terms of carbon content, revealing the key role of zooplankton in sardine diets (van der Lingen 2002, Garrido et al. 2008a, Espinoza et al. 2009). Still, phytoplankton contribution has been estimated to be as high as $19 \%$ of the mean annual dietary carbon of Sardina pilchardus in the Atlantic (Garrido et al. 2008a). The difference in the $\%_{C}$ between the 2 areas, i.e. the North Aegean Sea and the Atlantic coasts, could be explained by the smaller number of prey in the stomachs of sardines from the North Aegean Sea (maximum number $=3334$ prey) compared with those from Portugal (maximum number $\approx 7.5 \times 10^{6}$ prey).

The role of phytoplankton in sardine diets remains rather unclear. It has been suggested that phytoplankton are the main source of lipids (including poly-unsaturated fatty acids) for Sardina pilchardus (Garrido et al. 2007b, 2008b). Furthermore, a more herbivorous diet in sardines (compared to anchovies) may be related to their greater ability to utilize carbohydrates (van der Lingen 1995). Finally, sardines have been proposed to act as potential vectors of toxins to higher trophic levels due to the consumption of large amounts of toxin-producing diatoms (Pseudo- nitzschia spp.) and/or dinoflagellates (Dinophysis spp.) (Costa \& Garrido 2004, Garrido et al. 2008a). The numbers of toxin-producing diatoms and dinoflagellates were low in our samples compared to those found in the Iberian sardine (Garrido et al. 2008a); hence, sardine-mediated transfer of toxins to upper trophic levels is probably not important in the Aegean Sea.

\section{Ontogenetic differences in diet}

In contrast to adults with a diet that is numerically dominated by phytoplankton, juveniles of both Sardina and Sardinops can be considered as zooplanktophagous (Louw et al. 1998, Watanabe \& Saito 1998, the present study). In the present study, juveniles ingested only few phytoplankton cells and consumed mesozooplankton almost exclusively. The main explanation for this ontogenetic dietary change is the yet incomplete development of the feeding apparatus in the juvenile stage (Andreu 1969, King \& Macleod 1976). Both the number and the separating distance of the gill rakers and their denticles are functions of body size in Sardina pilchardus (Andreu 1969). When sardines reach the first year of life, the filtering apparatus is fully developed and has the necessary porosity to capture small prey (Andreu 1969).

\section{Feeding modes and selectivity}

Sardines originating from the Mediterranean Sea have fewer and more widely separated gill rakers than sardines from Atlantic waters (Andreu 1969). This differentiation was explained by Andreu (1969) as an adaptation to the higher plankton abundances found in the Atlantic that would favor filter feeding, while Mediterranean sardines would preferentially capture individual prey. The size frequency distributions of sardine prey from the North Aegean Sea seem to support Andreu's hypothesis. The 2 modes in number-based size frequency histograms of preys (Table 5) indicate that sardines are capable of both filter and particulate feeding. The $<200 \mu$ m mode included small prey (phytoplankton, microzooplankton and nauplii of copepods), whereas the 801-1000 $\mu \mathrm{m}$ or 1001-1200 $\mu \mathrm{m}$ (depending on the season) mode included larger organisms (e.g. Acartia clausi, Temora stylifera and Centropages typicus). However, carbonbased size frequency distributions clearly showed that smaller prey had a small contribution to dietary carbon (mainly in the stratified periods), whereas the 
larger organisms, although in low abundances in the field, were strongly selected (Table 1) and responsible for the bulk of dietary carbon. These results are in contrast with the findings of Garrido et al. (2008a), who found that small prey (50 to $150 \mu \mathrm{m}$ ) made the highest contribution to dietary carbon in sardines from the west and south coasts of Portugal (40\% and $30 \%$ on average, respectively). Hypothesizing a similar prey size for switching to particulate feeding as for Sardina pilchardus in the Atlantic (Garrido et al. 2007a), the smaller prey found in adult stomachs were most probably taken by filter feeding, while particulate feeding was used to capture larger prey (e.g. larger copepods and decapod larvae).

Sardina pilchardus presents selectivity for prey types during particulate feeding (Garrido et al. 2007a). Fish eggs were preferred over other prey types when sardines were fed on cultured, mixed prey assemblages, and copepods and decapods were selected over other zooplankton taxa when fed wildcollected, mixed prey assemblages (Garrido et al. 2007a). In our study area, certain prey groups (e.g. the Clauso-Paracalanidae) were detected in very low numbers in the stomachs compared to respective densities in the field and had low values for Ivlev's selectivity index. The mean size of ClausoParacalanidae $(721 \pm 135 \mu \mathrm{m})$ suggests that these copepods could be consumed during both filter and particulate feeding (according to the results of Garrido et al. 2007a); consequently, this prey type would be expected to occur in high numbers in sardine stomachs. A possible explanation for their negative selection could be the unusual swimming behavior exhibited by the genus Clausocalanus, involving a rapid and continuous movement in convoluted small loops (Mazzocchi \& Paffenhöfer 1999). This motion strategy is considered to be unique among small copepods and could possibly render the group of Clauso-Paracalanidae 'inaccessible' or energetically costly prey for sardines. In contrast, the swimming behavior of copepods that were preferentially ingested (e.g. Acartia clausi, Temora stylifera and Centropages typicus) is more predictable (e.g. Tiselius \& Jonsson 1990, Hwang \& Turner 1995, van Duren \& Videler 1995), probably making them easier to pursue and capture. Finally, other 'preferred' small copepods (e.g. the cyclopoid genus Oncaea as well as the harpacticoids Microsetella rosea and Euterpina acutifrons), known for their tendency to associate with detritus and/or gelatinous zooplankton (e.g. Green \& Dagg 1997, Diaz et al. 2003), could result into patches of abundant prey for sardines, especially when sardines employ filtering as the feeding mode.

\section{Dietary response to changes in the planktonic food web}

The oligotrophic conditions of the Eastern Mediterranean Sea were also evident in the coastal area of this study, especially in the stratified periods (July), when very low chl a values $\left(<0.2 \mu \mathrm{g} \mathrm{l}^{-1}\right)$ were recorded (Fig. 4). In these periods, indications that the food web was mainly based on microbial processes were found, i.e. the prevalence of small autotrophic cells (as shown by their carbon budget) (Fig. 7A) as well as high heterotrophic pico- and nanoplankton biomass compared to the autotrophic fraction. We may hypothesize that the prevalence of small autotrophic cells during summer could have resulted from the combined effects of the high temperatures recorded and/or the reduced grazing pressure by ciliates, the abundance of which was low (Fig. 5). High temperature has been considered to have a positive effect on picoplankton (Agawin et al. 2000), while ciliates are known to efficiently exploit pico- and nanoplankton (Rassoulzadegan et al. 1988), channeling energy to higher trophic levels (Pierce \& Turner 1992). Low ciliate abundances could have resulted from strong top-down control exerted by copepods because ciliates are known to compose an important part of copepod diets when phytoplankton concentrations are low (Calbet \& Saiz 2005). In the present study, smaller copepods (e.g. ClausoParacalanidae) that had higher abundance in the stratified than the mixing periods are known to be very efficient in exploiting the microbial food web components (Turner 2004). Finally, further support to our hypothesis is provided by the high abundances of cladocerans and appendicularians in summer, which have been shown to efficiently exploit pico- and nanoplankton through filter-feeding (e.g. Katechakis et al. 2004, Sommer \& Sommer 2006). To compensate for the low abundance of energy-rich prey (large copepods) during summer, sardines seemed to broaden their trophic niche by including other zooplankton prey (e.g. cladocerans, appendicularians, cirriped and gastropod larvae) in their diet, which were probably easier to capture using the less energy-demanding filtration mode (van der Lingen 1995). Filter-feeding on breeding aggregations of mature, houseless appendicularians, grouped near surface waters to spawn, has been reported as an alternative energy source for another SPF, the Argentine anchovy Engraulis anchoita (Capitanio et al. 2005).

In contrast, in February 2009 (the late phase of the mixing period), the carbon of autotrophs $>20 \mu \mathrm{m}$ 
( 300 $\mathrm{mg} \mathrm{C} \mathrm{m}^{-3}$ ) was $\sim 60$-fold higher than that of smaller autotrophs because diatoms and ADs were highly abundant (Fig. 5). This was indicative of the prevalence of the 'classical' food web, according to which larger copepods mediate between diatoms and fish (Cushing 1978). The high abundance of the larger ( $>1 \mathrm{~mm}$ TL) Centropages spp. ( $30 \%$ of the total mesozooplankton abundance) (see Fig. S1 in the supplement at www.int-res.com/articles/suppl/ m453p173_supp.pdf) in this particular period seems to concur with this structure (see Fig. 7B). Additionally, the higher abundance of ciliates in this period could be attributed to a possible decrease in the grazing pressure exerted on them, i.e. their contribution to copepod diets is expected to be lower when large phytoplankters are highly abundant (>50 $\mathrm{mg} \mathrm{C} \mathrm{m}^{-3}$ ) (Calbet \& Saiz 2005). Sardine diets in this period encompassed mainly the larger calanoid copepods Centropages spp. $\left(75 \%_{\mathrm{C}}\right)$, with lesser contribution from Clauso-Paracalanidae $\left(\sim 9 \%_{C}\right)$. The consumption of the latter group during this period could be the result of nighttime filter feeding because stomach fullness remained high in the early night (Nikolioudakis et al. 2011).

Finally, in December 2007 (the initial phase of mixing), an intermediate condition between those described previously for July and February seemed to occur, as indicated by the high chl a values, the similar carbon budget of small and large autotrophic cells and the dominance of autotrophic over heterotrophic biomass in pico- and nanoplankton. A transition from the highly oligotrophic conditions encountered during the stratified period seemed to be taking place in December 2007 towards the 'classical' (herbivorous) food web. Both the 'classical' and 'microbial' trophic pathways appeared to be active, possibly due to mixing and still relatively high temperatures. The high abundances of ciliates, appendicularians, cladocerans and smaller copepods recorded in December 2007 indicated that the microbial food web would sustain them, whereas the herbivorous pathway was able to support the larger copepods (e.g. Centropages typicus, Temora stylifera and Calanus spp.) that also showed increased abundances (compared to July, see Fig. S1 in the supplement). However, despite the multiple trophic pathways in place, sardines obtained the bulk of their dietary carbon from energy-rich, larger prey, such as C. typicus and Calanus spp., most likely selected with particulate feeding.

In summary, the changes observed in the food web (prevalence of small autotrophic cells versus large phytoplankters, e.g. diatoms) appeared to control the mean size of mesozooplankton, as implied in Fig. 7B. This in turn was depicted in the diet of sardines (Fig. 7C). Even in the stratified periods (Fig. 6), fish tended to select the larger available prey. The strong negative relationship between the diversity $\left(H^{\prime}\right)$ of prey in sardine stomachs and the mean size of the respective prey (Fig. 7D) suggests that the filter feeding mode (higher prey diversity) is used more than particulate feeding (selective feeding leading to lower prey diversity) when larger prey are less available (i.e. stratified periods). As observed in other areas of the world (van der Lingen et al. 2009), sardines in the oligotrophic Mediterranean Sea exhibit high plasticity and flexibility in feeding behavior, permitting the exploitation of a wide range of the prey size spectrum.

The information obtained from this and similar studies can be very useful in end-to-end modeling, specifically for the parameterization of plankton-fish interactions (Rose et al. 2010). The size-partitioned contribution of prey to a diet (e.g. Table 5) can be included in such models to more accurately represent the consumption of plankton by SPF and link the lower trophic level with fish bioenergetic models. Future work on Mediterranean sardines should be directed toward controlled tank experiments to (1) verify that both feeding modes are employed, (2) determine the exact prey size at which the switch between the 2 modes occurs and (3) test whether the density of prey controls the choice of feeding mode.

Acknowledgements. The present study was part of the European Project SARDONE (Improving assessment and management of small pelagic species in the Mediterranean, FP6-44294). The authors thank A. Machias, M. Giannoulaki, K. Tsagarakis, E. Schismenou and the captain and crew of the RV 'Philia', for their invaluable help during sampling, as well as the technical staff of HCMR who assisted in the present study. Thanks are also due to the entire SARDONE team, who collaborated in the preparation of a common protocol and the design of feeding studies for small pelagic fish in the Mediterranean, as well as to E. B. Morello for her help with PRIMER software and the 3 anonymous reviewers who helped us improve the manuscript.

\section{LITERATURE CITED}

Agawin NSR, Duarte CM, Agusti S (2000) Nutrient and temperature control of the contribution of picoplankton to phytoplankton biomass and production. Limnol Oceanogr 45:591-600

Anderson MJ, Gorley RN, Clarke KR (2008) PERMANOVA+ for PRIMER: guide to software and statistical methods. PRIMER-E, Plymouth, MA

Andreu B (1969) Las branquiespinas en la caracterización de las poblaciones de Sardina pilchardus (Walb.). Invest Pesq 33:425-607 
Antonakakis K, Giannoulaki M, Machias A, Somarakis S, Sanchez S, Ibaibarriaga L, Uriarte A (2011) Assessment of the sardine (Sardina pilchardus Walbaum, 1792) fishery in the eastern Mediterranean basin (North Aegean Sea). Mediterr Mar Sci 12:333-357

Ayón P, Swartzman G, Espinoza P, Bertrand A (2011) Longterm changes in zooplankton size distribution in the Peruvian Humboldt Current System: conditions favouring sardine or anchovy. Mar Ecol Prog Ser 422:211-222

> Bode A, Álvarez-Ossorio MT, Carrera P, Lorenzo J (2004) Reconstruction of trophic pathways between plankton and the North Iberian sardine (Sardina pilchardus) using stable isotopes. Sci Mar 68:165-178

Calbet A, Saiz E (2005) The ciliate-copepod link in marine ecosystems. Aquat Microb Ecol 38:157-167

Capitanio FL, Pájaro M, Esnal GB (2005) Appendicularians: an important food supply for the Argentine anchovy Engraulis anchoita in coastal waters. J Appl Ichthyol 21: 414-419

> Caron DA, Dam HG, Kremer P, Lessard EJ and others (1995) The contribution of microorganisms to particulate carbon and nitrogen in surface waters of the Sargasso Sea near Bermuda. Deep-Sea Res I 42:943-972

Clarke KR, Gorley RN (2006) PRIMER v6: User manual/ tutorial. PRIMER-E, Plymouth, MA

Clarke KR, Warwick RM (1994) Change in marine communities: an approach to statistical analysis and interpretation. Plymouth Marine Laboratory, Plymouth, MA

Costa PR, Garrido S (2004) Domoic acid accumulation in the sardine Sardina pilchardus and its relationship to Pseudo-nitzschia diatom ingestion. Mar Ecol Prog Ser 284:261-268

> Cunha ME, Garrido S, Pissarra J (2005) The use of stomach fullness and colour indices to assess Sardina pilchardus feeding. J Mar Biol Ass UK 85:425-431

Cushing DH (1978) Upper trophic levels in upwelling areas. In: Boje $\mathrm{R}$, Tomczak $\mathrm{M}$ (eds) Upwelling ecosystems. Springer-Verlag, New York, NY, p 101-110

Diaz E, Cotano U, Villate F (2003) Reproductive response of Euterpina acutifrons in 2 estuaries of the Basque Country (Bay of Biscay) with contrasting nutritional environment. J Exp Mar Biol Ecol 292:213-230

> Espinoza P, Bertrand A, van der Lingen CD, Garrido S, Rojas de Mendiola B (2009) Diet of sardine (Sardinops sagax) in the northern Humboldt Current system and comparison with the diets of clupeoids in this and other eastern boundary upwelling systems. Prog Oceanogr 83:242-250

> Field JG, Clarke KR, Warwick RM (1982) A practical strategy for analysing multispecies distribution patterns. Mar Ecol Prog Ser 8:37-52

- Fileman ES, Fitzgeorge-Balfour T, Tarran GA, Harris RP (2011) Plankton community diversity from bacteria to copepods in bloom and non-bloom conditions in the Celtic Sea in spring. Estuar Coast Shelf Sci 93:403-414

Garrido S, Marçalo A, Zwolinski J, van der Lingen CD (2007a) Laboratory investigations on the effect of prey size and concentration on the feeding behaviour of Sardina pilchardus. Mar Ecol Prog Ser 330:189-199

Garrido S, Rosa R, Ben-Hamadou R, Cunha ME, Chícharo MA, van der Lingen CD (2007b) Effect of maternal fat reserves on the fatty acid composition of sardine (Sardina pilchardus) oocytes. Comp Biochem Physiol B 148: 398-409

Garrido S, Ben-Hamadou R, Oliveira PB, Cunha ME, Chícharo MA, van der Lingen CD (2008a) Diet and feed- ing intensity of sardine Sardina pilchardus: correlation with satellite-derived chlorophyll data. Mar Ecol Prog Ser 354:245-256

Garrido S, Rosa R, Ben-Hamadou R, Cunha ME, Chícharo MA, van der Lingen CD (2008b) Spatio-temporal variability in fatty acid trophic biomarkers in stomach contents and muscle of Iberian sardine (Sardina pilchardus) and its relationship with spawning. Mar Biol 154: 1053-1065

> Giannoulaki M, Pyrounaki MM, Liorzou B, Leonori I and others (2011) Habitat suitability modelling for sardine juveniles (Sardina pilchardus) in the Mediterranean Sea. Fish Oceanogr 20:367-382

Green EP, Dagg MJ (1997) Mesozooplankton associations with medium to large marine snow aggregates in the northern Gulf of Mexico. J Plankton Res 19:435-447

Hillebrand H, Dürselen CD, Kirschtel D, Pollingher U, Zohary T (1999) Biovolume calculation for pelagic and benthic microalgae. J Phycol 35:403-424

> Hwang JS, Turner JT (1995) Behaviour of cyclopoid, harpacticoid, and calanoid copepods from coastal waters of Taiwan. PSZN I: Mar Ecol 16:207-216

> Hyslop EJ (1980) Stomach contents analysis - a review of methods and their application. J Fish Biol 17:411-429

> Isari S, Ramfos A, Somarakis S, Koutsikopoulos C, Kallianiotis A, Fragopoulu N (2006) Mesozooplankton distribution in relation to hydrology of the Northeastern Aegean Sea, Eastern Mediterranean. J Plankton Res 28:241-255

Isari S, Psarra S, Pitta P, Mara P and others (2007) Differential patterns of mesozooplankters' distribution in relation to physical and biological variables of the northeastern Aegean Sea (eastern Mediterranean). Mar Biol 151: 1035-1050

Isari S, Somarakis S, Christou ED, Fragopoulu N (2011) Summer mesozooplankton assemblages in the northeastern Aegean Sea: the influence of Black Sea water and an associated anticyclonic eddy. J Mar Biol Ass UK 91:51-63

Ivlev VS(1961) Experimental ecology of the feeding of fishes. Yale University Press, New Haven, CT

James AG (1987) Feeding ecology, diet and field-based studies on feeding selectivity of the Cape anchovy Engraulis capensis Gilchrist. In: Payne AIL, Gulland JA, Brink KH (eds) The Benguela and comparable ecosystems. S Afr J Mar Sci 5:673-692

James AG (1988) Are clupeoid microphagists herbivorous or omnivorous? A review of the diets of some commercially important clupeids. S Afr J Mar Sci 7:161-177

Kana T, Glibert PM (1987) Effect of irradiances up to $2000 \mu \mathrm{E} \mathrm{m} \mathrm{m}^{-2} \mathrm{~s}^{-1}$ on marine Synechococcus WH7803: I. Growth, pigmentation, and cell composition. Deep-Sea Res A 34:479-495

Katechakis A, Stibor H, Sommer U, Hansen T (2004) Feeding selectivities and food niche separation of Acartia clausi, Penilia avirostris (Crustacea) and Doliolum denticulatum (Thaliacea) in Blanes Bay (Catalan Sea, NW Mediterranean). J Plankton Res 26:589-603

King DPF, Macleod PR (1976) Comparison of the food and filtering mechanism of pilchard Sardinops ocellata and anchovy Engraulis capensis off South West Africa, 19711972. Investl Rep Sea Fish Brch S Afr 111:1-29

Lee S, Fuhrman JA (1987) Relationships between biovolume and biomass of naturally derived marine bacterioplankton. Appl Environ Microbiol 53:1298-1303

Legendre L, Rassoulzadegan F (1995) Plankton and nutrient 
dynamics in marine waters. Ophelia 41:153-172

Louw GG, van der Lingen CD, Gibbons MJ (1998) Differential feeding by sardine Sardinops sagax and anchovy Engraulis capensis recruits in mixed shoals. S Afr J Mar Sci 19:227-232

Massuti M, Oliver M (1948) Estudio de la biometría y biología de la sardina de Mahón (Baleares), especialmente de su alimentación. Bol Inst Esp Oceanogr 3:1-15

Mazzocchi MG, Paffenhöfer GA (1999) Swimming and feeding behaviour of the planktonic copepod Clausocalanus furcatus. J Plankton Res 21:1501-1518

Menden-Deuer S, Lessard EJ (2000) Carbon to volume relationships for dinoflagellates, diatoms, and other protist plankton. Limnol Oceanogr 45:569-579

Moyle PB, Senanayake FR (1984) Resource partitioning among the fishes of rainforest streams in Sri Lanka. J Zool 202:195-223

Nikolioudakis N, Palomera I, Machias A, Somarakis S (2011) Diel feeding intensity and daily ration of the sardine Sardina pilchardus. Mar Ecol Prog Ser 437:215-228

Palomera I, Olivar MP, Salat J, Sabatés A, Coll M, García A, Morales-Nin B (2007) Small pelagic fish in the NW Mediterranean Sea: an ecological review. Prog Oceanogr 74:377-396

Pierce RW, Turner JT (1992) Ecology of planktonic ciliates in marine food webs. Rev Aquat Sci 6:139-181

> Porter KG, Feig YS (1980) The use of DAPI for identifying and counting aquatic microflora. Limnol Oceanogr 25: 943-948

Rassoulzadegan F, Laval-Peuto M, Sheldon RW (1988) Partitioning of the food ration of marine ciliates between pico- and nanoplankton. Hydrobiologia 159:75-88

Rose KA, Allen JI, Artioli Y, Barange M and others (2010) End-to-end models for the analysis of marine ecosystems: challenges, issues, and next steps. Mar Coast Fish Dynam Manag Ecosys Sci 2:115-130

Schoener TW (1970) Nonsynchronous spatial overlap of lizards in patchy habitats. Ecology 51:408-418

Schwartzlose RA, Alheit J, Bakun A, Baumgartner TR and others (1999) Worldwide large-scale fluctuations of sardine and anchovy populations. S Afr J Mar Sci 21: 289-347

Siokou-Frangou I, Bianchi M, Christaki U, Christou ED and others (2002) Carbon flow in the planktonic food web along a gradient of oligotrophy in the Aegean Sea (Mediterranean Sea). J Mar Syst 33-34:335-353

Siokou-Frangou I, Christaki U, Mazzocchi MG, Montresor M, Ribera D'Alcala M, Vaque D, Zingone A (2010) Plankton in the open Mediterranean Sea: a review. Biogeosciences 7:1543-1586

Somarakis S, Palomera I, Garcia A, Quintanilla L, Koutsikopoulos C, Uriarte A, Motos L (2004) Daily egg production of anchovy in European waters. ICES J Mar Sci 61: 944-958

Sommer U, Sommer F (2006) Cladocerans versus copepods: the cause of contrasting top-down controls on freshwater

Editorial responsibility: Konstantinos Stergiou,

Thessaloniki, Greece and marine phytoplankton. Oecologia 147:183-194

Strickland JDH, Parsons TR (1972) A practical handbook for sea water analysis, 2nd edn. Bull Fish Res Board Can 167:1-311

> Tiselius P, Jonsson PR (1990) Foraging behavior of 6 calanoid copepods: observations and hydrodynamic analysis. Mar Ecol Prog Ser 66:23-33

Tomas CR (1996) Identifying marine phytoplankton. Academic Press, London

> Tsagarakis K, Coll M, Giannoulaki M, Somarakis S, Papaconstantinou C, Machias A (2010) Food-web traits of the North Aegean Sea ecosystem (Eastern Mediterranean) and comparison with other Mediterranean ecosystems. Est Coast Shelf Sci 88:233-248

Turner JT (2004) The importance of small planktonic copepods and their roles in pelagic marine food webs. Zool Stud 43:255-266

van der Lingen CD (1994) Effect of particle size and concentration on the feeding behaviour of adult pilchard, Sardinops sagax. Mar Ecol Prog Ser 109:1-13

van der Lingen CD (1995) Respiration rate of adult pilchard Sardinops sagax in relation to temperature, voluntary swimming speed and feeding behaviour. Mar Ecol Prog Ser 129:41-54

van der Lingen CD (2002) Diet of sardine Sardinops sagax in the southern Benguela upwelling ecosystem. S Afr J Mar Sci 24:301-316

> van der Lingen CD, Hutchings L, Field JG (2006) Comparative trophodynamics of anchovy Engraulis encrasicolus and sardine Sardinops sagax in the southern Benguela: Are species alternations between small pelagic fish trophodynamically mediated? Afr J Mar Sci 28:465-477

van der Lingen C, Bertrand A, Bode A, Brodeur R and others (2009) Trophic dynamics. In: Checkley DM, Alheit J, Oozeki Y, Roy C (eds) Climate change and small pelagic fish. Cambridge University Press, Cambridge

van Duren LA, Videler JJ (1995) Swimming behaviour of developmental stages of the calanoid copepod Temora longicornis at different food concentrations. Mar Ecol Prog Ser 126:153-161

Varela M, Alvarez-Ossorio MT, Valdés L (1990) Método para el estudio cuantitativo del contenido estomacal de la sardina. Resultados preliminares. Bol Inst Esp Oceanogr 6:117-126

- Watanabe Y, Saito H (1998) Feeding and growth of early juvenile Japanese sardines in the Pacific waters off central Japan. J Fish Biol 52:519-533

Yentsch CS, Menzel DW (1963) A method for the determination of phytoplankton chlorophyll and phaeophytin by fluorescence. Deep-Sea Res Oceanogr Abstr 10:221-231

Zar JH (1999) Biostatistical analysis, 4th edn. Prentice Hall, Englewood Cliffs, NJ

Zervoudaki S, Christou ED, Nielsen TG, Siokou-Frangou I and others (2007) The importance of small-sized copepods in a frontal area of the Aegean Sea. J Plankton Res 29:317-338

Submitted: September 5, 2011; Accepted: February 8, 2012 Proofs received from author(s): April 22, 2012 